Max-Planck-Institut für demografische Forschung

Max Planck Institute for Demographic Research

Konrad-Zuse-Strasse 1 - D-18057 Rostock - GERMANY

Tel +49 (0) 3812081 - 0; Fax +49 (0) 3812081 - 202;

http://www.demogr.mpg.de

MPIDR WORKING PAPER WP 2011-001

JANUARY 2011

\title{
Stem families, joint families, and the \\ European pattern: how much of a reconsideration do we need?
}

\author{
Siegfried Gruber (gruber@demogr.mpg.de) \\ Mikołaj Szołtysek (szoltysek@demogr.mpg.de)
}

(C) Copyright is held by the authors.

Working papers of the Max Planck Institute for Demographic Research receive only limited review. Views or opinions expressed in working papers are attributable to the authors and do not necessarily reflect those of the Institute. 


\title{
Stem families, joint families, and the European pattern: How much of a reconsideration do we need?
}

\author{
Siegfried Gruber, Mikołaj Szołtysek \\ Laboratory of Historical Demography \\ Max Planck Institute for Demographic Research
}

\section{Introduction}

The use of scientific samples of census data that are comparable across space and time is revolutionizing research into demography, economics, and family history. Among the many issues discussed in association with these new developments in data infrastructure, the questions of who lives with whom, and for what reasons, remain central (King and Preston 1990). Variations in components of the co-resident domestic groups are often considered the most crucial indicators of diversity in family systems. Diversity in people's living arrangements reflects a variety of preferable or achievable residential patterns, and likely indicates differential notions regarding the way obligations to kin from outside the immediate family are structured. The study of residence patterns not only contributes to a better understanding of household composition; it is also of primary importance in explaining demographic outcomes. As recent research suggests, domestic groups formed according to stem- and joint-family rules would make for different fertility outcomes. Moreover, these groups may perform welfare functions towards their members on a different basis, and may cope with economic hardships in a different manner (Laslett 1972, 1988; Cain 1991; Das Gupta 1997; Skinner 1997; Bengtsson, Campbell and Lee 2004).

The starting points for this paper are two recent contributions to the discussion of family systems published in Population and Development Review by Steven Ruggles (Ruggles 2009; Ruggles 2010). In the first of these studies, Ruggles compared the living arrangements of the elderly on the basis of 87 censuses of 34 countries from around the world. He used six control variables to test whether a distinctive "Northwest European family pattern" can be proved. By comparing the observed and predicted levels of co-residence in the cross-temporal and cross-national census collection, Ruggles sought to refute the idea of the existence of a European and North American exceptionalism in nuclear family residence. In a recent paper, Ruggles again used a huge assemblage of census microdata to assess the spatiotemporal distribution of stem- and joint-family arrangements in 35 historical and contemporary populations. Using two measures of co-residence among the aged and basic 
controls for agricultural employment and demographic structure, he argued that European and North American societies "have had a long standing aversion to joint-family living arrangements." According to Ruggles, this lack of a joint-family organization is a truly defining feature of the "European family pattern," past and present (Ruggles 2010, 564) ${ }^{1}$.

Eastern and Southeastern European census samples were also used in these two articles. They showed that there were higher proportions of multi-generational households in these regions than in Northwestern Europe and North America, but lower proportions than in other non-European countries (Ruggles 2009). Stem families were found to be more prevalent in Eastern and Southeastern Europe than in Western Europe or North America, but less common than in other non-European countries. According to Ruggles, joint families were quite rare in the European East and Southeast, with Greece being the only exception. Whereas for stem families the predicted and the observed levels of co-residence match up quite well, the observed percentages of joint families in Greece were consistently higher than the shares that had been predicted (Ruggles 2010). Ruggles' major conclusion is that the measure of joint family structure is not closely tied to basic measures of demography or agricultural employment, and therefore that cultural, rather than structural, factors might be responsible for the variations in the frequency of this type of co-residence (ibid. 574).

Ruggles' recent papers make valuable contributions to the discussion of family forms. His renewed affirmation of the role of demographic factors in accounting for differentials in family structure is likely to inspire further research into the factors responsible for the variations in residence patterns across the globe. Nevertheless, although Ruggles characterizes his most recent analysis as representing Europe in its entirety, his paper actually lacks evidence from pre-1980 continental Europe, and from Eastern Europe in particular. Whereas the oldest data used by Ruggles dates from 1851, the eastern part of the continent is represented in his last paper by only five countries, for which census records go back no more than 40 years from the present time. The structure of the current IPUMS and NAPP collections prevents Ruggles from capturing broader European dimensions with regards to

\footnotetext{
${ }^{1}$ Ruggles' usage of the term "Europe" is not very consistent throughout the paper. While he was careful in restricting its geographical scope to the northwestern part of the continent in some points in his paper, in others he referred to Europe seemingly in its entirety. While this may have been meant to represent broader European dimensions, or was intended as a shorthand for denoting specifically Western European phenomena, it nonetheless creates potential confusion about what should be considered as belonging to the "European repertoire" of family characteristics (esp. Ruggles 2010, 574; comp. Todorova 2001).
} 
family characteristics. In particular, the limits of Ruggles' sample made it impossible for him to recognize the true prevalence of joint families in a broader European context. As rich as the IPUMS and NAPP collections currently are, they are still not rich enough to justify the breadth of the claims Ruggles has made. This paper is an attempt to go beyond these limitations.

Through our own analysis of newly available census microdata, we present in this paper evidence of joint-family co-residence in historic Eastern Europe. We demonstrate that the IPUMS/NAPP samples contain no traces of joint families in Eastern Europe due to insufficient spatial and time coverage for Eastern European regions, and show that jointfamily arrangements have been common in at least some of these eastern areas in the recent and more distant past. If our argument is correct, then Ruggles' observation that "the real European pattern concerns the lack of joint families" (Ruggles 2010, 574) would need to be revised. Accordingly, the notion that "Europeans ... have had a long standing aversion to joint family arrangements" might appear to be equally misleading. Finally, we suggest that Ruggles' definitions of stem- and joint-family households are too crude to capture the diversity of living arrangements that have been found in historical data.

For the most part, we followed the methodology set out in the two papers by Ruggles mentioned above. We used his dataset, but we enriched it with a new collection of census microdata from Eastern, Central, and Southeastern Europe from between the late $18^{\text {th }}$ and early $20^{\text {th }}$ centuries. To this new assemblage of data, we generally applied the same set of measures and control variables as Ruggles in the regression analysis, and we used nearly the same prediction model, amending it only slightly by reducing the number of outlying observations. Using more elaborate procedures to define stem and joint-family co-residence, we also make a case for methodological refinement that can help to remove biases inherent in Ruggles' investigation into the degree to which adults related by blood, marriage, or adoption live together.

In line with Ruggles, we initially observed that the frequency of joint-family arrangements in the regions under study cannot be fully accounted for by referring to measures of economic conditions and demographic structures alone. Although our model has a better predictive power, a significant part of the observed variation in elderly co-residence patterns still remains unexplained. In the final section of the paper, we speculate about some additional factors which may account for the observed differences in joint-family co-residence across historic Eastern Europe. 


\section{Data and regions}

Starting with the data Ruggles used for his recent article (Ruggles 2010), we constructed the corresponding variables for our collection following his approach. To investigate whether Ruggles' hypotheses about the proportions of stem and joint families also hold true for Eastern Europe in the past, we used historical census microdata from three different countries of the region: the Polish-Lithuanian Commonwealth in the end of the $18^{\text {th }}$ century, Jasenica county in central Serbia in the $19^{\text {th }}$ century, and Albania in 1918.

The first compilation (The CEURFAMFORM Database) contains data on 21,132 rural households from late-18th-century Poland-Lithuania, belonging to 236 parishes and 900 settlements, and with an overall population of nearly 130,000 persons. The data were derived from various types of population enumerations listing individuals by residential units, with kinship relationships made transparent within each domestic group ${ }^{2}$. More than 90 percent of these listings come from the period 1766-1799. The territories under study cover the western and southern fringes of the Polish-Lithuanian Commonwealth (regions 1 to 5, 6+7); eastwards into the borderland between present-day Poland, Belarus, and Ukraine (reg. 8); and then even farther east into Belarus, south from Minsk (reg. $11 \mathrm{~N}$ and $11 \mathrm{~S}$ respectively); and into western Ukraine (reg. 10). Various parts of this data collection have already been analyzed (Szołtysek and Rzemieniecki 2005; Szołtysek 2008a, 2008b, 2009; Szołtysek and Zuber 2010).

The Serbian data consist of the population censuses of 1863 and 1884 for eight villages in the district of Jasenica in Central Serbia, including the village of Orašac (Halpern, 1958, 1972). The basic results of these censuses were officially published (Državopis 1865 , 1889). The results of the research into household structures were also previously published (Gruber 2003, 2004, 2009). The small number of elderly people makes it necessary to treat these two sources together.

From January 1916, Northern and Central Albania was occupied by the AustroHungarian army, and a population census was taken on March 1, 1918. The checking and the processing the data had to be stopped due to the planned withdrawal of the army in October. The order to destroy all of the census material was ignored except in some areas in the south of the occupied territory (Seiner 1922, 5). The surviving material, which covers the major part of the country, therefore includes 435,836 out of the 524,217 persons who lived in about

\footnotetext{
${ }^{2}$ The database development was supported by the Marie Curie Intra-European Fellowship project (FP6-2002-Mobility-5, Proposal No. 515065) at the Cambridge Group for the History of Population and Social Structure, Cambridge, UK, 2006-2008.
} 
1,800 villages, towns, and cities in the territory administered by Austria-Hungary during World War I. The census director published basic tables in 1922, supported by funds from the Albanian government (Seiner 1922) ${ }^{3}$.

Even though the data span great distances of space, and originate from different administrative practices, they provide generally comparable information on living arrangements. The majority of individuals in our collection were listed by domestic groups comprising all of the people occupying separate residential units, sharing meals, and living under the supervision of the household head. Such units consisted not only of the head's core family, but also of his immediate and more distant relatives, as well as co-resident servants and inmates or lodgers. There were some inconsistencies in the way domestic groups were represented in the two Balkan censuses (particularly in urban sites). However, this had almost no effect on our estimations of the living arrangements of the aged (less than one percent of them could be affected by differences in definitions). For most individuals, the information on his/her name and surname, age, and kin relation to other household members was either explicitly given or could be easily inferred.

The Polish-Lithuanian sample comprises exclusively rural societies engaged in smalland middle-scale farming. An overwhelming majority of the population of all regions were serfs living in personal and hereditary subjugation. The Polish (and Catholic) preponderance over western areas (regions 1-7) was diminishing in favor of large numbers of Belarussians and Ukrainians (mostly Uniates, i.e., Greco-Catholics) in the eastern provinces $(8,10,11 \mathrm{~N}$, and 11S). This ethnic and religious divide on historical Polish territories was a long-lived one, and it retained its spatial validity well into the 1920s and 1930s.

The population in the Albanian census was predominantly Muslim (78.2 percent), with a Catholic minority in the north (18.6 percent) and an Orthodox minority in the south (3.1 percent), and was almost exclusively Albanian. The economy was dominated by agriculture, and the urban population made up only 13.2 percent of the total. Very few Albanian adults who lived outside of the cities were literate.

\footnotetext{
${ }^{3}$ The census material is still stored in the archives of the Austrian Academy of Sciences in Vienna. The research project "The 1918 Albanian Population Census: Data Entry and Basic Analyses" (http://www-gewi.uni-graz.at/seiner/index.html) was funded by the Austrian Science Fund, and was aimed at translating the data into a machine-readable format. This data has been used for analyses of household structures, ages at marriage, and migration (Gruber 2005, 2008, 2009, 2010; also Kera and Pandelejmoni 2008).
} 
Most of the land in Serbia was owned by smallholders, and over the course of the 19th century, the focus of their activities shifted from animal husbandry to agriculture. Pigs were the main source of cash income for the rural population (Palairet 1997, 94). The crop yields per hectare were among the lowest in Europe (Sundhaussen 1989, 235, 261; Sundhaussen 2007, 177), and the peasant economy was still overwhelmingly oriented towards subsistence (Gruber 2004, 181f.). The people who lived in these eight villages were almost all of Serbian nationality, and were members of the Orthodox Church.

Comparing Albania from 1918 with Poland-Lithuania of the $18^{\text {th }}$ century may raise some questions. Sklar has noted that marriage behavior among the populations of the Czech, Baltic, and Polish regions differed from that of the people living in the Balkan countries during the demographic transition (Sklar 1974), which makes it particularly interesting to compare these two regions. In addition, to test the applicability of Ruggles' model, we needed populations among whom a considerable proportion were living in joint-family constellations, and both of our datasets fulfil this requirement. The Albanian population census of 1918 and the Polish-Lithuanian database are the only existing databases of historical census microdata in Eastern and Southeastern Europe that are large enough to allow for an investigation of demographic conditions and household compositions for several regions within a country.

Even though our Eastern and Southeastern European data span long periods of time, from a demographic perspective, these are pre-transitional populations. In the majority of historical Polish territories, the demographic transition did not start before the end of the $19^{\text {th }}$ century, and the Belarussian population exhibited the highest fertility levels in Eastern Europe well into 1920s (Fogelson 1938). Albania was the last country in Europe to enter the demographic transition (i.e., after the Second World War).

\section{Variables and data exploratory analysis}

In order to compare patterns of living arrangements, Ruggles used the living arrangements of individuals and couples aged 65 or older. Looking at the residence patterns from the perspective of the elderly makes it possible to partly overcome the weaknesses of householdlevel variables, such as those used in the Hammel-Laslett model, which is popular among family historians (Berkner 1977; Ruggles 1986, 1987, 1990, 2009; King and Preston 1990; King 1990). Measuring co-residence from the perspective of the elderly minimizes the effects of variation in demographic conditions on indicators of family structure. The majority of older people have the demographic potential to reside with offspring, even in populations in which few households have the potential to include elderly kin. 
Like Ruggles, we defined the elderly population as persons aged 65 or older, and we treated married couples in which both partners were aged 65 or older as single observations, since they shared a single living arrangement (Ruggles 2009, 252f.). Accordingly, our analysis focuses on the residence of these elderly people in multi-generational households. Again like Ruggles (2010), we subdivided multi-generational households into stem-family households and joint-family households in order to capture two distinct manifestations of the complexity of family co-residence. In the first part of our analysis, the operationalization of our two dependent variables was based on definitions suggested by Ruggles $(2010,566)$. Stem-family households were multi-generational co-resident groups with no more than one married child. Joint-family households were multi-generational co-resident groups with two or more married children. In later sections of the paper, we present our refined measures of stem- and joint-family living arrangements ${ }^{4}$.

We also constructed simple control variables to account for regional variations in demographic conditions in our datasets (Table 1). These variables are identical to those used by Ruggles, and the detailed descriptions and rationale for each of them are documented in his

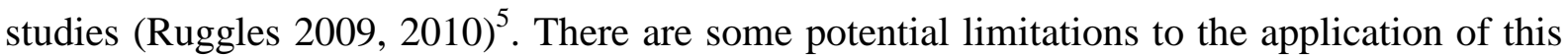
standard set of predictors to our Eastern and Southeastern European data. In particular, the variable agricultural employment, which was of key theoretical importance in Ruggles' works, had to be operationalized differently in our case. Information about occupations is missing in most of the Serbian data, but since these data refer to populations engaged predominantly in agriculture, we assumed that all persons without a stated form of employment outside of agriculture were employed in agriculture. There is also no information on social class or the occupation of household heads in the Polish-Lithuanian dataset, although we know that the data deal with exclusively rural populations. Therefore, the rate of agricultural employment was diversified using background information about the prevailing ecological conditions and economic activities other than farming among regional peasant strata. In the Albanian census, about one-third of the male population of working age has either no reported occupation, or was said to "help his relatives." These men are grouped into the occupational sector of the head of their household. In addition, there is information

\footnotetext{
${ }^{4}$ All of these measures are designed to assess living arrangements through family relationships only among people co-residing in the same household.

${ }^{5}$ Wherever it was necessary, we used the same standard population as Ruggles, which was the average across all census samples originally used in his paper.
} 
available for agricultural activities. All men whose occupation is still unknown, but who were involved in agricultural activity, are grouped into the agricultural sector. The remaining men are coded as being non-agricultural. Marital fertility can be slightly overestimated in our samples. The census takers usually reported the number of children from the point of view of the mostly male household heads, and therefore some of the wives would have been the stepmothers of the children in the household. Marital status is not given in the Serbian census of 1863, and these data are derived from the information about the presence of a spouse or of children. We assume that men with unknown marital status in the age group 20-24 years were unmarried, and that men in all older age groups were either married or widowed. The quality of marital status reporting in the late 18th-century Poland-Lithuania also varied, as information on the marital status of life-cycle servants, some lodgers, and elderly solitary women was frequently missing. All of the servants are assumed to be unmarried (see Szołtysek 2009 for an explanation). In a few regions where the proportion of never-married women increased considerably after the age of 34 , the distribution of people by marital status was adjusted to the lowest proportion of celibates in the given dataset. Finally, the numbers of cases of our datasets are much smaller than Ruggles' collections, and might therefore be more affected by the values of single cases.

\section{Table 1 somewhere here}

Table 1 summarizes regional variations for the nine predictors in our datasets. The Polish-Lithuanian and Albanian datasets are of nearly the same size, while both are much larger than the Serbian component of our collection. The values of all of the independent variables differ significantly both between the largest groupings, and between the regions within them. The percent values for the elderly population and the proportions of the nevermarried among those aged 45-54 varied particularly between all of the regions. For other variables, however, the variation was smaller. Still, the populations under study differed markedly with regards to nuptiality. For the most part, males in Albania married very late, well above the age of 25, as did men in some western regions of historical Poland. By contrast, male Serbians, Ukrainians, and Belarussians tended to marry at much younger ages. The female ages at marriage were, meanwhile, generally consistent with the characteristics of Hajnal's "joint household formation systems" (Hajnal 1982, 452). The average age at first marriage among women was under 21 for the whole of Albania, and was as low as under age 19 in Poland's eastern regions. Only in the western Polish regions did the average female age 
at marriage rise above 21-22 years. Differences in the female age at marriage were particularly dramatic across the territories of historical Poland.

\section{Table 2 somewhere here}

Table 2 summarizes regional variations for the two measures of living arrangements, and this time also includes large data groupings from Ruggles' collection. Ruggles has noted that the lowest percentages for living in stem families were observed for Western Europe in the $20^{\text {th }}$ and $21^{\text {st }}$ centuries, and for the Nordic countries in the $19^{\text {th }}$ century. Whereas North America has slightly higher rates, the rates from the $20^{\text {th }}$ and $21^{\text {st }}$ centuries in Eastern and Southeastern Europe are much closer to the rates of Western Europe and North America than to those of other regions in the world (particularly in Asia). However, new datasets from historic Eastern Central and Southeastern Europe show rates of living in stem families that are very close to the rates of the Asian and African samples in Ruggles' data. The Serbian rate, in particular, is almost as high as the Asian mean. The highest rates for some single regions within our new datasets are almost as high as the highest country means recorded for Asian or African countries. These regions are the district of Elbasan-South in Albania and region 8 in the Polish-Lithuanian dataset (today western Ukraine), where more than 50 percent of the elderly were living in stem families, according to Ruggles' definition. In Albania, the proportions in the north were generally higher than in the central part of the country, while the western part of Poland-Lithuania also had generally lower rates than the eastern parts of the country. At least in this regard, Serbia was much more similar to northern Albanian and to the eastern part of the Polish-Lithuanian areas than to the other regions. A marked exception is the low proportion of elderly people living in stem families in region 1 of northern Poland inhabited by German Protestants, which is lower than in any country in Ruggles' dataset ${ }^{6}$.

The share of the elderly living in joint families is generally much lower. The Western European and North American countries have rates that are consistently below one percent. The contemporary Eastern and Southeastern European samples have only 1.8 percent on average, with only Greece in 1971 reaching 6.5 percent. This level is only surpassed by East and South Asian data, while the averages for the other regions fall between these extremes. Only four countries (Iraq 1997, Vietnam 1989, China 1990 and 1982) have shares of elderly

\footnotetext{
${ }^{6}$ Unfortunately, Ruggles' dataset does not have comparable information from Germany or Scandinavian countries from the $20^{\text {th }}$ century.
} 
living in joint families that are above 10 percent. In contrast, the Albanian census of 1918 has a proportion of 13.9 percent, the Polish-Lithuanian dataset has an average of 15.7 percent, and the Serbian sample even has an average of 27.5 percent; making these datasets comparable to the highest rates of single countries in Ruggles' dataset. The Polish-Lithuanian data reveal a marked difference between the region's western and eastern halves: the western part of the region has rates that are very similar to those seen in $19^{\text {th }}$-century Western Europe, while the rate of joint-family co-residence in the eastern half of the region is, at 24.3 percent, higher than in any country in Ruggles' collection, and is second only to that of the Serbian sample. Within Albania, we again see higher rates in the northern parts and lower rates in the central parts of the country. The only exceptions are the region North2, with less than 10 percent; and the region South, with 16.6 percent. Regarding living in stem families, the Albanian urban data resemble data from North America in the $19^{\text {th }}$ century and from the Latin American or Middle Eastern samples in the $20^{\text {th }}$ century. The proportion of elderly urban Albanians living in joint families is even more exceptional. With values of 9.5 percent, it is higher than any African sample in Ruggles' data. The highest rates can be found for regions 11S and 10 in the eastern part of historic Poland-Lithuania (today southern Belarus and northern Ukraine), where more than 30 percent of the elderly were living in joint families-more than in any Albanian or Serbian region, and far more than in any country in Ruggles' collection.

This exploratory analysis points to the existence of regions with widespread joint living arrangements in Eastern and Southeastern Europe. They also confirm the existing knowledge that the complexity of households was higher in the north of Albania than in its central parts, and higher in the east than in the west of Poland-Lithuania (Mosely 1976, 60-68 and Todorova 1993, 149; Szołtysek 2008a, 2008b). But we must still determine whether these exceptional proportions of joint families can be explained by demographic rates and agricultural activities alone, or whether some other factors should be considered. We also want to know whether the striking differences within countries can, to a high degree, be explained by the control variables.

\section{Predicting elederly living arrangements}

In line with Ruggles, we used ordinary least squares regression to control for the effects of variation in economic and demographic conditions on the living arrangements of the elderly across the samples. Accordingly, the main goal of the regression exercise was to assess systematically whether the level of co-residence in a particular country or region was high or 
low, given the demographic and economic circumstances. Our strategy relies on using the regression to predict the living arrangements of the aged in each census sample, and then to compare this predicted family structure with the observed values. This is how we would gauge whether a given population had higher or lower levels of elderly co-residence than would be expected on the basis of that population's economic and demographic characteristics (Ruggles 2009, 258).

The results of the country-level analysis overlap almost completely with Ruggles' original estimations (Ruggles 2010, 572). They show that stem families in Poland-Lithuania and Serbia fit relatively well into the prediction. Only for Albania were the observed values significantly lower than would be expected given the economic and demographic characteristics of the population. Like in Ruggles' analysis, the comparable model for joint families revealed a much less clear association between predicted and observed values. All of the countries with a proportion of joint families above 10 percent had substantially higher observed rates than those that were predicted, and our three datasets also showed this pattern. We suspect, however, that lumping together different regions of Poland-Lithuania and Albania may mask heterogeneity within our "samples."

To account for this variation, we split the Polish data into western and eastern components, and repeated the whole exercise (Figures 1a and 1b). Looking at stem-family co-residence, we found that the observed and the predicted percentages match almost exactly for eastern Poland, while the country's western territories had much lower observed values than predicted. For the Serbian data, the model was found to be a good fit. An interesting aspect of this model's fit is that neither of these two societies had a tradition of stem-family household formation rules or characteristic patterns of co-residence, whereas there was an indication of a stem-family pattern in Polish western regions (Szołtysek 2007). When looking at percentages of joint families, we can see that Poland's west hugs the left axis very much like the Western European countries. On the other hand, Poland's east, together with Serbia, are the two cases with the largest differences between the observed and the predicted percentages. The gap between the western and eastern territories of Poland seems to be as large as it possibly could be.

\section{Figures 1a and 1b: somewhere here}

To learn more about the effects of regional variation in our Eastern and Southeastern European data, we ran an additional model which included Polish-Lithuanian and Albanian 
datasets, which were this time divided into their regional components (the overall number of observations was increased from 103 to 122, with Serbia treated as single case) (Table 3). The model's fit for stem families decreased (to 0.68), while it increased slightly for joint families (.41). By adding our 22 regions to Ruggles' original stem-family model, we had to remove the effects of several variables previously significant (i.e., male and female marriage). Regarding joint-family co-residence, the crucial difference brought about by the new model was to make the inverse relationship with female age at marriage significant.

\section{Table 3: somewhere here}

Figures 2a and 2b plot observed against predicted values for the model discussed above. Most of our Eastern European regions cluster around the diagonal of predicted and observed percentages living in stem families, with the exception of the Polish region 1 only. Again, the goodness-of-fit of the model is surprising for our Eastern European populations who adhered to a lesser extent to stem family rules. All of the eastern Polish regions except for one are dispersed below the prediction line, and the same is true for half of Albanian regions and for Serbia with regards to living in joint families. For all of them, the predictive power of the model is very weak. Five Albanian regions and Polish eastern region 8 are the only ones for which the prediction works quite well. The rest of our collection are strongly clustered near the left axis, and display values of joint family co-residence that are much lower than predicted.

\section{Figures 2a and 2b: somewhere here}

Almost 50 percent of all of the observations in Ruggles' collection concerned populations with less than two percent of the elderly living in joint families. We believe this could distort the overall model for joint families simply by including countries for which there will never be any joint families, regardless of how the control variables are changed. To minimize these effects, we re-ran this model only for those countries for which the rate of elderly co-residence was at least two percent (the number of observations thus dropped to $59)^{7}$

\footnotetext{
${ }^{7}$ In practice, this led to a circumvention of the comparison of our Eastern European data with data from Middle Eastern, African, and Asian countries (with the exception of Greece). Five out of six Polish western regions were now also excluded from the modeling.
} 


\section{Table 4: somewhere here}

The new regression model of residence in joint families (Table 4) is more powerful (40 percent increase of adjusted R-square from 0.41 to 0.57 ). The variables significantly associated with the joint family indicator are now female age at marriage; the de jure rules of enumeration; the percentage of never-married, unmarried elderly women; and the proportion of the elderly. Male marriage now has a negative sign (but remains non-significant), which makes sense because a low male age at marriage increases the potential for co-residence with married offspring among the elderly. The proportion of the elderly becomes significant, but is now positively associated with a joint-family measure, which runs counter to theoretical expectations. More confusing is the fact that agricultural employment now becomes negatively related to the dependent variable, although it remains non-significant.

\section{Figure 2c: somewhere here}

The goodness-of-fit of this new model is illustrated with Figure 2c. What is striking is the lack of real outliers in the new version of the scatterplot. Up to a certain point, all of the current observations are scattered equally on both sides of the diagonal. The model seems to work particularly well for Albania. For the two Polish eastern regions with the highest propensity for joint-family co-residence (regions 10 and $11 \mathrm{~N}$ ), as well as for Serbia, it is weaker. Therefore, there is still something left unexplained by a simple structural model in elderly co-residence patterns in these regions of Eastern and Southeastern Europe (43 percent of the observed variation remains unexplained), even after the countries with no signs of joint-family organization have been excluded. It may well be that for these regions to fit into the predicted pattern, an additional factor not covered by the control variables, like the ecotype or a cultural disposition to live together with relatives in the same household, should be taken into account.

\section{Measuring elderly living arrangements with new definitions}

Ruggles defined stem-family households as multi-generational co-resident groups with no more than one married child. Accordingly, he defined joint-family households as multigenerational co-resident groups with two or more married children. He also argued that his two measures of multi-generational co-residence capture properly both stem- and joint-family arrangements (Ruggles 2010, 265-266). We think that this is not entirely true. 
First, the stem-family system may include a variety of household forms, and there is disagreement about exactly how to define it, particularly with quantitative measures in the cross-section (Rebel, 1978, 256-260; Berkner, 1976, 84-91; Verdon, 1979; Cartier 1995; Saito 1998; also Kertzer 1995, 377; recently Ehmer 2009; Fauve-Chamoux and Ochiai 2009). Second, under the pre-transitional patterns of high mortality, which are applicable at least to our historical datasets, many of the truly multi-generational co-resident groups (that is, resulting from either stem- or joint-family household formation rules) might well be composed of co-resident "truncated" families-e.g., an elderly couple residing with a widowed son or daughter and their grandchildren (Ruggles 1986; Hammel 1990). Thus, it seems more reasonable to base the definition of multiple-family co-residence on the notion of a "conjugal family unit" rather than on married couples, whereby the main structural principle of the conjugal family unit (CFU) would be the existence of a husband-wife or parent-child relationship (Hammel and Laslett 1974). Third, given the "perennial" multiple family arrangements that are known to have existed in some parts of historical Eastern Europe (Czap 1982), a considerable proportion of elderly people may actually have co-resided with married lateral kin rather than with children or children-in-law, or with both types of kin. In many pretransitional societies, joint-family arrangements implied a patrilateral (and, less frequently, a matrilateral) extension to the core family. The most important relatives for such additional units were the CFUs of brothers, nephews, or cousins (Plakans 1975) ${ }^{8}$. We found numerous cases of this type of residential arrangement in our Albanian, Polish, and Serbian datasets.

Following this rationale, we redefined both forms of complex family arrangements in our datasets. Our definition of living in stem families includes living with a CFU of a child, child-in-law, or grandchild. Living with a CFU of a child (or child-in-law) and a CFU of a grandchild also fit this definition, while the presence of two or more CFUs of children and children-in-law, or of two or more CFUs of grandchildren, make the household a joint-family domestic group. Accordingly, we consider not only those elderly who live with two or more married children to be living in joint families, but also those living with all kinds of married lateral relatives (or, more precisely, CFUs belonging to them). In these residential arrangements, living with a married nephew would therefore substitute for living with a married child. Our definition of living in a joint family can also be reduced to a simple formula: it is living in a multiple-family household according to the Hammel-Laslett scheme

\footnotetext{
${ }^{8}$ The distinction we propose corresponds to the differentiation between "paternal" and "fraternal zadrugas." Ruggles' definition of joint-family co-residence does not capture the latter one.
} 
which is not a stem family according to our definition. We believe that if we miss a major part of co-residence with married relatives from the point of view of the elderly, the results of an analysis of joint family arrangements might be biased. These joint-family co-residence patterns would be underestimated, especially in societies with a higher proportion of lateral extensions within the household.

The results of these adjustments are given in Figures 3a and 3b. Regarding the stem family measure, there is only one region in our dataset with a complete match between our ("living in stem families") and Ruggles' ("living with one married child") definitions (region $11 \mathrm{~N}$ in Poland-Lithuania), although the overall differences are generally small. Ruggles' notion of stem-family co-residence clearly underestimates the extent of this family form among most of the Polish regions, as well as in Serbia. On the other hand, it overestimates the proportion of the elderly in stem families of the majority of Albanian regions (the largest observed difference amounts to 12 percent).

\section{Figures 3a and 3b: somewhere here}

In the case of joint families, the two definitions diverge much more strongly (Figure $3 \mathrm{~b})$. All of our cases are now located to the right of the diagonal, indicating a general increase in the proportions of elderly in joint-family co-residence as we define it, compared to Ruggles' measures. The Polish-Lithuanian regions and Serbia, however, are more similar in both measures of living in joint families, whereas most Albanian regions display striking differences in this regard. In Poland-Lithuania the highest increase in joint family coresidence occurs in the region $11 \mathrm{~S}$, which is characterized by the highest proportion of joint family arrangements (increase from 33 to 45 percent). However, in many of the Albanian regions, the increases reach 20 and 30 percent, with a maximum of 40 percent in ElbasanNorth. Overall, we see that the fit of Ruggles' definition of joint families with our definition is 80 percent for the Serbian dataset, 78 percent for the Polish-Lithuanian dataset, but only 37 percent for the Albanian dataset. The new definition we propose here would increase the analytic power of the used models, especially in the case of the Albanian data, but probably also for other countries displaying high incidence rates of joint-family co-residence. This would also decrease possible biases because the fit between these two measures in our regional data differs from a mere 10 percent to 95 percent.

Table 5: somewhere here 
Our new definitions have tended to show increases in the complexity of the living arrangements of the aged, and have never shown a decrease (Table 5). All of those who were living in joint-family arrangements according to Ruggles' definition remained in the same family constellations, but some moved from stem to joint families (in Albania, almost one in four of those defined as living in stem families according to Ruggles). In addition, a fraction of those elderly people who were classified by Ruggles as living in neither stem- nor jointfamily arrangements were reclassified as members of stem or joint families according to our definition (again, especially in Albania). The reasons for the increase in joint families in the new definition are co-residence arrangements with married or widowed nephews, brothers, or cousins. In Albania, more people moved from stem to joint families than from other to stem families, which therefore led to a decrease in the share of elderly people living in stem families (according to our second definition) ${ }^{9}$.

\footnotetext{
${ }^{9}$ We assessed the impact of these two definitions of joint families on the data files used by Ruggles and found only minor effects. These findings are in clear contrast to those from the Albanian data, and thus demand an explanation. This explanation can be provided by the proportion of lateral kin within the population, i.e., relatives who are not descendents or ancestors (including their spouses) of the
} heads of households or their spouses. This proportion was 26.7 percent in the Albanian census of 1918, 18.9 percent in the Serbian sample, and 17.0 and 13.0 percent in regions $11 \mathrm{~N}$ and $11 \mathrm{~S}$ of Poland-Lithuania. In the IPUMSInternational data files, only two countries (Ghana 2000 and Guinea 1996) have rates similar to these (21.8 and 17.6 percent, respectively). Most non-European countries have rates of up to five percent. If we consider only the married population, i.e., the population who are responsible for creating additional joint families, the percentages are lower, at 19.6 percent in Albania, 14.6 percent in Serbia, and 16.6 and 9.5 percent in two regions of historical Poland. The IPUMSInternational data files contain only three countries with shares of at least five percent: Ghana 2000 with 14.5 percent, Guinea 1996 with 10.1 percent, and Iraq 1997 with 5.0 percent. Only in these countries are some major changes due to different definitions of joint families possible. Iraq 1997 is actually the case with the highest proportion of joint families in Ruggles' paper, and could have had even higher proportions according to our definition. But the following countries (Vietnam and China) have a share of one percent or less of lateral kin among the married population, and thus no increase in joint families would have been possible. The definitional difference matters only for populations with high proportions of lateral kin in the households, which are almost absent in most contemporary populations. The only regions where we have found higher proportions of these kin are sub-Saharan Africa and the Middle East. Historical populations, on the other hand, can have quite high proportions of lateral kin incorporated into households. Our conclusion is that the differences between these two definitions of joint families do not matter very much for the majority of the populations currently 
Another problem with Ruggles' definition of stem-family co-residence is that it does not distinguish between "true" stem-family arrangements (i.e., resulting from stem-familyspecific household formation rules and life cycle), and those which might result from the "reincorporation" of the elderly into their children's homes after they become unable to care for themselves (Kertzer 1995). Ruggles argued that this was not a problem in his data. He presented a figure showing that in $19^{\text {th }}$-century Canada and the United States, as well as in historical northern Europe, most multi-generational households were headed by the older generation (Ruggles 2010, 262-263). Unfortunately, this reasoning does not fully apply to our historical data, no matter which definition of stem family we use, Ruggles' or our own. In historical western Poland, 83 percent of the elderly living in stem-family arrangements, as defined by Ruggles, were not heading households. This number drops substantially in the Polish eastern regions. However, even in these areas, almost 32 percent of the aged were not household heads. Both in Serbia and in Albania, around 64 percent of the aged in stem families were not household heads. Distinguishing between two qualitatively different types of co-residence within the "stem-family group" is not easy. It would require additional conceptual work and further exploration of the data, which is beyond the scope of this paper.

\section{Conclusions}

At the outset of this paper, we suggested that the limits of IPUMS samples make it impossible to determine the true prevalence of joint families in a broader European context. The inclusion of historical datasets from Eastern and Southeastern Europe into the analysis has indeed revealed the existence of societies with a high proportion of elderly people living in stem- or joint-family arrangements. The rates of joint-family co-residence among the aged were much higher in these past societies than in any other European country in Ruggles' data. These findings seem to suggest that not all Europeans in all historical periods had an "aversion" to living in joint families.

Our contribution certainly is not all-encompassing with regards to delineating joint family zones in Europe. Since the works of Milovan Gavazzi and Michael Mitterauer, we have had quite a good sense of when and where in the history of European peoples the joint family made an appearance, and that these regions were by no means confined to Belarus,

covered by IPUMSInternational and NAPP, but that they may matter upon the inclusion of more historical data, as well as of census samples from African societies in the future. 
Ukraine, and Albania (Gavazzi 1980; Mitterauer 1981; also Kosven 1963; Wheaton 1975; Kaser 2000). Laterally extended families have been present in such diverse places as $15^{\text {th }}$ century Tuscany, early modern France (Berkner and Schaffer 1978), 19 ${ }^{\text {th }}$-century northern Italy (Kertzer 1989), Finland (Waris 2002), and, of course, in the paradigmatic Russian case (Czap 1982). Traces of domestic groups structured along joint-family principles were also found to be present among early medieval Germanic societies (Gavazzi 1980, 167-168). Apart from Albania, joint-family households appear to have been a common form of household organization in some other areas of the Balkans in the past (Kaser 1996).

If, then, traces of joint-family co-residence emerge from the results and literature presented in this paper, what difference does it make? If not all Europeans were averse to living in joint families, then it appears that more conscious efforts to understand what constituted the "European pattern" should be made. In order to examine to what extent jointfamily co-residence might have been a part (even if only a minor one) of the European repertoire of family systems, the expansion of research into broader European regions and different historical periods might be necessary. New initiatives in data infrastructures, most notably the continuing extensions of the IPUMS and NAPP collections, are very promising in this regard.

Our analysis of family forms in the vast Eastern European territories challenges at least some of the assumptions made in the older literature dealing with spatial aspects of European family systems (e.g., Burguière \& Lebrun, 1986, 38; Thornton, 2005, 52). Both the Polish-Lithuanian and Albanian datasets revealed striking internal variation in the propensity to live in more complex domestic groups. These findings regarding the diversity of family forms in historical Eastern Europe should finally free us from simplistic views of the continent's familial history, and particularly from the notion of a "dividing line" (Hajnal 1965, 1982). It is also likely that a certain level of variation in residence patterns might have featured in other European countries as well (Wall 1991; Szołtysek 2010; Szołtysek et.al. 2010). Up to this point, tackling this problem by using integrated and harmonized census microdata series has not yet been attempted.

The results of our analysis demonstrate that, while Ruggles' definition of stem families is consistent with the stem-family arrangements in our data, his definition of joint families does not cover a major part of the joint-family arrangements in those new datasets, especially in the Albanian regions. As comparative research on residence patterns is likely to grow worldwide, future researchers working with new culture-specific datasets will have to work out properly contextualized definitions of complex family arrangements. Only then can 
we prevent biases from interfering with our efforts to investigate the degree to which adults related by blood, marriage, or adoption live together.

Explaining why there are the differences in the rates of joint-family arrangements in different places and at different points in time remains a challenge. Our analysis confirmed Ruggles' earlier assertions that the observed frequency of joint-family arrangements cannot be fully accounted for by referring to measures of economic conditions and demographic structures alone. The regions with the highest proportions of joint-family arrangements in our datasets have higher observed percentages than those that were predicted. This suggests that not all relevant information has been included in the model, and that we should think about adding more variables. Nevertheless, we think that an "aversion" to one form of domestic group structure or another was hardly the only factor, or even the most decisive factor affecting the observed complexity of family patterns, at least across historic Eastern Europe. While it is likely that cultural influences played some role in fostering the complexity of residential arrangements, many differences in the observed patterns of joint-family patterns across Europe could be satisfactorily explained by a mixture of economic, ecological, and institutional factors, or, better, constraints (see Verdon 1998). The voluminous research on household complexity in the Balkans provides a sufficient number of examples of this kind of reasoning (Brunnbauer 2003, 2004). There is also abundant evidence suggesting that Eastern European landlords or other powerful authorities were customarily concerned with their subjects' residential arrangements. They often required the latter to be modified, and usually had the power to implement their wishes (Szołtysek and Zuber 2010). It has been shown that the interference of landlords led to the formation of a much greater number of complex households than would have been the case if peasants had been free from feudal or military obligations (Vaniček 1875; Kaser 1986; Grandits 2002; Hammel 1995; Szołtysek and Zuber 2010; see also Alderson and Sanderson 1991). Cultural differences, ecotype specificities, and political economic and demographic factors might be the pieces of a puzzle that has yet to be put together in the realm of studies of family systems.

\section{Acknowledgements}

This article is a revised and expanded version of the paper presented at $35^{\text {th }}$ Annual SSHA meeting (Chicago, 18-21 November 2010). We wish to thank Steven Ruggles, who generously supplied us with the data of the 100 cases he used for his article in 2010. We also want to thank Rebecca Emigh and Joshua Goldstein for their comments on an earlier version of this paper. 


\section{Literature cited:}

Alderson, Arthur S., and Stephen K. Sanderson. 1991. "Historic European household structures and the capitalist world-economy", Journal of Family History 16(4): 419-432.

Bengtsson, Tommy, Campbell, Cameron and James Z. Lee. 2004. Life Under Pressure: Mortality and Living Standards in Europe and Asia, 1700-1900. Cambridge, MA: MIT Press.

Berkner, Lutz K. 1976. "Inheritance, Land Tenure and Peasant Family Structure: A German Regional Comparison," in Jack Goody, Joan Thirsk and Edward P. Thompson (eds.), Family and Inheritance in Rural Western Europe, 1200-1700. Cambridge: University Press, pp. 71-95. . 1977. "Household Arithmetic: a Note," Journal of Family History 2 (2): 159-163.

Berkner, Lutz K., and John W. Shaffer. 1978. "The Joint Family in the Nivernais," The Journal of Family History 3: 150-162.

Brunnbauer, Ulf. 2003. "Descent or territoriality. Inheritance and family forms in the late Ottoman and early post-Ottoman Balkans", in Hannes Grandits und Patrick Heady (eds.), Distinct inheritances. Property, family and community in a changing Europe. Münster: Lit-Verlag, pp. 293-321.

2004. Gebirgsgesellschaften auf dem Balkan. Wirtschaft und Familienstrukturen im Rhodopengebirge (19./20. Jahrhundert). Wien/Köln/Weimar: Böhlau.

Burch, Thomas K. 1967. "The size and structure of families: A comparative analysis of census data," American Sociological Review 32 (3): 347-363.

1970. "Some Demographic Determinants of Average Household Size: An Analytic Approach," Demography 7 (1): 61-70.

1980. "The index of overall headship: a simple measure of household complexity standardized for age and sex," Demography 17 (1): 25-37.

Burch, Thomas K., Shiva S. Halli, Ashok K. Madan, Kausar Thomas, and Lokky Wei. 1987. "Measures of household composition and headship based on aggregate routine census data," in John Bongaarts, Thomas K. Burch and Kenneth W. Wachter (eds.), Family demography: methods and their application. Oxford: Oxford University Press, pp. 19-39.

Burguère, Andre, and Francis LEBRUN. 1986. "Les Cent et une familles de l'Europe," in A. Burguière et.al. (eds.), Historire de la Famille, vol. 2. Paris: Armand Colin, pp. 21-122.

Cain, Mead. 1991. "Welfare Institutions in Comparative Perspective: The Fate of the Elderly in Contemporary South Asia and Pre-Industrial Western Europe," in Margareth Pelling and Richard M. Smith (eds.), Life, death, and the elderly: historical perspectives. London [et. al.]: Routledge, pp. 222- 243.

Cartier, Michel. 1995. "Nuclear versus quasi- stem families: the new Chinese family model", Journal of Family History 20(3): 307-27.

Czap, Peter. 1982. "The Perennial Multiple Family Household, Mishino, Russia 1782 - 1858," Journal of Family History 7: 5-26.

Das Gupta, Monica. 1997. „Kinship systems and demographic regimes”, in David I. Kertzer and Tom Fricke (eds.), Anthropological demography: toward a new synthesis. Chicago: University of Chicago Press, pp. 36-52.

Ehmer, Josef. 2009. "House and the Stem Family in Austria," in Antoinette Fauve-Chamoux and Emiko, Ochiai (eds.), The Stem Family in Eurasian Perspective. Bern: Peter Lang, pp. 46-64. Fauve-Chamoux, Antoinette, and Emiko Ochiai. 2009. "Introduction," in Antoinette FauveChamoux and Emiko Ochiai (eds.), The Stem Family in Eurasian Perspective. Bern: Peter Lang, pp. 1-50.

Fogelson, Samuel. 1938. "Z badań nad demografią Polesia i Wołynia," Prace Wydziatu PopulacyjnoMigracyjnego 6: Instytut badań Spraw Narodowościowych, Warszawa.

French, R.A. and Smith, R.E.F., 1970, The terminology of settlements and their lands in late medieval Russia. Discussion Papers No. 7 (Series RC/D), Centre for Russian and East European Studies, August.

Gavazzi, Milovan. 1980. "Die Mehrfamilien der Europäischen Völker," Ethnologia Europaea 11: 158190. 
Gieysztorowa, Irena, 1976, Wstęp do demografii staropolskiej, PWN, Warszawa.

Grandits, Hannes. 2002. Familie und sozialer Wandel im ländlichen Kroatien (18.-20. Jahrhundert) (Zur Kunde Südosteuropas II/32). Wien, Köln, Weimar: Böhlau.

Gruber, Siegfried. 2003. "Auf der Suche nach serbischen Lebensläufen des 19. Jahrhunderts," Anzeiger für Slavische Philologie XXXI: 163-78.

2004. Lebensläufe und Haushaltsformen auf dem Balkan: das serbische Jasenica im 19. Jahrhundert. Unpublished doctoral thesis, Karl-Franzens-Universität Graz. 2005. "Occupational migration in Albania in the beginning of the 20th century," in Humanities, Computers and Cultural Heritage: Proceedings of the xvith international conference of the Association for History and Computing. Amsterdam, pp. 136-142. . 2008. "Household structures in urban Albania in 1918," in Gentiana Kera, Gijs Kessler, (eds.), Urban Household and Family in Twentieth Century East and South-East Europe. Amsterdam: Elsevier, pp. 138-151.

2009. "Household Formation and Marriage: Different Patterns in Serbia and Albania?," in Antoinette Fauve-Chamoux and Ioan Bolovan (eds.), Families in Europe between the $19^{\text {th }}$ and $21^{\text {st }}$ Centuries: From the Traditional Model to the Contemporary PACS (Romanian Journal of Population Studies Supplement). Cluj-Napoca: Presa Universitară Clujeană, pp. 229-247. 2010. "Marriage Patterns in Northern Albania in the Beginning of the $20^{\text {th }}$ Century," in MariePierre Arrizabalaga, Ioan Bolovan, Marius Eppel, Jan Kok and Mary Louise Nagata (eds.), Many Paths to Happiness? Studies in Population and Family History. A Festschrift for Antoinette Fauve-Chamoux. Amsterdam: aksant, pp. 404-426.

Hajnal, John. 1953. "Age at Marriage and Proportions Marrying," Population Studies 7(2): 111-36. . 1965. "European marriage patterns in perspective" in David V. Glass and David E. C. Eversley (eds.), Population in History. Essays in historical demography. London: Edward Arnold, pp. 101-143.

1982. "Two kinds of preindustrial household formation system," Population and Development Review 8 (3): 449-494.

Halpern, Joel M. 1958. A Serbian Village. New York: Columbia University Press.

- 1972. "Town and countryside in Serbia in the nineteenth century: social and household structure as reflected in the census of 1863," in Peter Laslett and Richard Wall (eds.), Household and family in past times. Cambridge: Cambridge University Press, pp. 401-427.

Hammel, Eugene A. 1990. "Demographic Constraints on the Formation of Traditional Balkan Households," Dumbarton Oaks Papers 44: 173-186.

1995. "Economics 1, Culture 0: Fertility Change and Differences in the Northwest Balkans, 1700-1900," in Susan Greenhalgh (ed.), Situating Fertility: Anthropology and Demographic Inquiry. Cambridge: Cambridge University Press: pp. 225-258.

Hammel, Eugene A., and Peter Laslett. 1974. "Comparing household structure over time and between cultures," Comparative Studies in Society and History 16: 73-109.

Kaser, Karl. 1986. Freier Bauer und Soldat. Die Militarisierung der agrarischen Gesellschaft in der kroatisch-slawonischen Militärgrenze (1535-1881) (Zur Kunde Südosteuropas II/15). Graz: Institut für Geschichte der Universität Graz.

1996. "Introduction: Household and family contexts in the Balkans", The History of the Family 1(4), pp. 375-386.

2000. Macht und Erbe. Männerherrschaft, Besitz und Familie im östliche Europa (15001900). Wien: Böhlau.

Kera, Gentiana, and Enriketa Pandelejmoni, 2008. "Marriage in urban Albania (during the first half of the twentieth century)," in Gentiana Kera and G. Kessler (eds.), Urban Household and Family in Twentieth Century East and South-East Europe. Amsterdam: Elsevier, pp. 126-137.

Kertzer, David I. 1989. "The joint family revisited: Demographic constraints and complex family households in the European past," Journal of Family History 14: 1-15.

1991. "Household history and sociological theory," Annual Review of Sociology 17: 155-179.

. 1995. "Toward a Historical Demography of Aging," in David I. Kertzer and Peter Laslett

(eds.), Aging in the Past: Demography, Society, and Old Age. Berkeley: University of

California Press, pp. 363-383.

King, Miriam. 1990. "All in the Family? The Incompatibility and Reconciliation of Family 
Demography and Family History," Historical Methods 23: 32-40.

King, Miriam, and Samuel H. Preston. 1990. "Who Lives with Whom? Individual versus Household Measures," Journal of Family History 15 (2): 117-132.

Kosven, Mark O., 1963, Semeinaia obshchina i patronimiia, Izd-vo Akademii Nauk SSSR, Moscow.

Laslett, Peter. 1972. "Introduction", in Peter Laslett and Richard Wall (eds.), Household and family in past time. Cambridge: Cambridge University Press, pp. 1-89.

- 1988. "Family, kinship and collectivity as systems of support in preindustrial Europe: a consideration of the »nuclear-hardship« hypothesis", Continuity and Change 3(2): 152-175.

Mitterauer, Michael. 1981. "Komplexe Familienformen in sozialhistorischer Sicht," Ethnologia Europaea 12: 213-271.

Mosley, Philip E. 1976. "The Distribution of the Zadruga within Southeastern Europe," in Robert F. Byrnes, Leonard Schapiro and Philip E. Mosley (eds.), Communal Families in the Balkans: The Zadruga. Notre Dame: University of Notre Dame Press, pp. 58-69.

Palairet, Michael. 1997. The Balkan economies c. 1800-1914: Evolution without development (Cambridge Studies in Modern Economic History 6). Cambridge: Cambridge University Press.

Plakans, Andrejs. 1975. "Seigneurial Authority and Peasant Family Life: The Baltic Area in the Eighteenth Century," Journal of Interdisciplinary History 5 (4): 629-654.

Rebel, Hermann. 1978. "Peasant Stem Families in Early Modern Austria: Life Plans, status tactics, and the grid of inheritance." Social Science History 2 (3): 255-291.

Ruggles, Steven. 1986. "Availability of Kin and the Demography of Historical Family Structure," Historical Methods 19: 93-102.

1987. Prolonged Connections: The Rise of the Extended Family in Nineteenth-Century England and America. Madison: University of Wisconsin Press. . 1990. "Family Demography and Family History: Problems and Prospects," Historical Methods 23: 22-30.

2009. "Reconsidering the Northwest European Family System: Living Arrangements of the Aged in Comparative Historical Perspective," Population and Development Review 35 (2): 249-273.

2010. "Stem Families and Joint Families in Comparative Historical Perspective," Population and Development Review 36 (3): 563-577.

Saito, Osamu. 1998. "Two Kinds of Stem Family System? Traditional Japan and Europe Compared," Continuity and Change 13 (1): 167-186.

Seiner, Franz. 1922. Ergebnisse der Volkszählung in Albanien in dem von den österr.-ungar. Truppen 1916-1918 besetzten Gebiete (Schriften der Balkankommission, Linguistische Abteilung 13). Wien: Hölder-Pichler-Tempsky.

Skinner, George W. 1997. "Family systems and demographic processes," in David I. Kertzer and Tom Fricke (eds.), Anthropological Demography: Toward A New Synthesis. Chicago: University of Chicago Press, pp. 53-95.

Sklar, June L. 1974. "The role of marriage behaviour in the demographic transition: the case of Eastern Europe around 1900," Population Studies 28 (2): 231-247.

Sundhaussen, Holm. 1989. Historische Statistik Serbiens 1834-1914. Mit europäischen Vergleichsdaten (Südosteuropäische Arbeiten 87). München: Oldenbourg. 2007. Geschichte Serbiens. 19. bis 21. Jahrhundert. Wien: Böhlau.

Szołtysek, Mikolaj. 2007. "Central European household and family systems, and the "HajnalMitterauer" line: the parish of Bujakow (18th-19th centuries)," History of the Family 12: 1942.

2008a. "Three kinds of preindustrial household formation systems in historical Eastern: challenge to spatial patterns of the European family," The History of the Family 13 (3): 223257.

2008b. "Rethinking Eastern Europe: household formation patterns in the Polish-Lithuanian Commonwealth and European family systems," Continuity and Change 23: 389-427.

2009. "Life cycle service and family systems in the rural countryside: a lesson from historical East-Central Europe," Annales de Démographie Historique 1: 53-94.

2010. "Spatial construction of European family and household systems: promising path or 
blind alley? An Eastern European perspective", paper presented at 35th Annual Meeting of the Social Science History Association (SSHA), Chicago (USA), November 2010.

Szołtysek, Mikolaj, and Konrad Rzemieniecki. 2005. "Between »traditional« collectivity and »modern « individuality: an atomistic perspective on family and household astride the Hajnal's line (Upper Silesia and Great Poland at the end of the $18^{\text {th }}$ century)," Historical Social Research 30: 130-170.

Szołtysek, Mikolaj and Barbara Zuber-Goldstein. 2010. "Historical family systems and the great European divide: the invention of the Slavic East," Demográfia: English Edition 52(5): 5-47.

Szołtysek, Mikolaj, Gruber, Siegfried, Klüsener, Sebastian and Joshua R.Goldstein. 2010. "Spatial variation in household structure in 19th-century Germany", MPIDR Working Paper, WP2010-030.

Thornton, Arland. 2005. Reading history sideways. The fallacy and enduring impact of the developmental paradigm on family life. Chicago: University of Chicago Press.

Todorova, Maria. 1993. Balkan Family Structure and the European Pattern. Demographic Developments in Ottoman Bulgaria. Washington, DC: American University Press. 2001. "On the epistemological value of family models: the Balkans within the European pattern," in Richard Wall, Tamara K. Hareven, and Josef Ehmer with the assistance of Marcus Cerman (eds.), Family History Revisited. Comparative Aspects. Newark: University of Delaware Press, pp. 242-256.

Vaniček, Franz. 1875. Specialgeschichte der Militärgrenze. Wien.

Verdon, Michel. 1979. "The Stem Family: Toward a General Theory," Journal of Interdisciplinary History 10 (1): 87-105.

- 1998. Rethinking Households: An Atomistic Perspective on European Living Arrangements. London: Routledge.

Vuletić, Aleksandra. 2002. Porodica u Srbiji sredinom 19. veka (Istorijski Institut, posebna izdanja 35). Beograd.

Wall, Richard. 1991. "European family and household systems", in Historiens et populations. Liber Amicorum Etienne Helin. Louvain-la-Neuve: Academia, pp. 617-636.

Waris, Elina. 2002. "Komplexe Familienformen. Neue Forschungen zu Familie und Arbeitsorganisation im finnischen Karelien und in Estland," Historische Anthropologie 10(1): $31-51$.

Wheaton, Robert. 1975. "Family and Kinship in Western Europe: The Problem of the Joint Family Household," Journal of Interdisciplinary History 5 (4): 601-628. 
Tables and figures

TABLE 1 Characteristics of census samples and values of variables used in the analysis

\begin{tabular}{|c|c|c|c|c|c|c|c|c|c|c|c|}
\hline \multirow[b]{2}{*}{ Region } & $\begin{array}{l}\text { Agricultural } \\
\text { employment }\end{array}$ & $\begin{array}{l}\text { Percent } \\
\text { elderly }\end{array}$ & Marital fertility & $\begin{array}{c}\text { Female } \\
\text { marriage } \\
(\mathrm{SMAM})\end{array}$ & $\begin{array}{c}\text { Male marriage } \\
\text { (SMAM) }\end{array}$ & Non-marriage & $\begin{array}{l}\text { Unmarried } \\
\text { elderly women }\end{array}$ & Elderly couples & De jure census & \multirow[b]{2}{*}{ Population } & \multirow[b]{2}{*}{ Households } \\
\hline & $\begin{array}{l}\text { Log of } \% \text { men } \\
\text { aged } 18-64 \\
\text { employed in } \\
\text { agriculture }\end{array}$ & $\begin{array}{c}\% \text { of } \\
\text { population } \\
\text { aged } 65 \text { or } \\
\text { older }\end{array}$ & $\begin{array}{c}\text { Age- } \\
\text { standardized } \\
\text { marital fertility } \\
\text { ratio }\end{array}$ & $\begin{array}{c}\text { Female } \\
\text { singulate age } \\
\text { at marriage }\end{array}$ & $\begin{array}{c}\text { Male singulate } \\
\text { age at } \\
\text { marriage }\end{array}$ & $\begin{array}{c}\% \text { never married } \\
\text { at ages } 45-54 \\
\text { (both sexes) }\end{array}$ & $\begin{array}{c}\% \text { pop } 65+\text { who } \\
\text { are women } \\
\text { without spouses }\end{array}$ & $\begin{array}{c}\% \text { pop } 65+\text { who } \\
\text { are residing with } \\
\text { spouse }\end{array}$ & $\mid \begin{array}{c}\text { De jure census } \\
\text { enumeration } \\
\text { rule }\end{array}$ & & \\
\hline Albania 1918 & 4,3 & 5,1 & 60,6 & 18,6 & 27,2 & 3,8 & 47,9 & 40,0 & 1 & 140611 & 27794 \\
\hline North1 & 4,6 & 4,8 & 55,1 & 17,8 & 27,3 & 4,7 & 36,4 & 44,6 & 1 & 6857 & 1057 \\
\hline Northeast & 3,9 & 4,6 & 46,5 & 20,9 & 29,2 & 2,6 & 32,5 & 47,8 & 1 & 13309 & 2696 \\
\hline North-Center & 4,5 & 5,1 & 55,3 & 17,3 & 26,8 & 3,1 & 54,0 & 34,9 & 1 & 9503 & 1864 \\
\hline Center & 4,5 & 4,7 & 58,7 & 17,1 & 25,7 & 4,4 & 51,9 & 37,9 & 1 & 6147 & 891 \\
\hline Center-West & 4,4 & 3,4 & 62,3 & 18,2 & 22,6 & 0,1 & 39,8 & 45,4 & 1 & 8838 & 1756 \\
\hline Elbasan- $\mathrm{N}$ & 4,5 & 4,5 & 60,7 & 21,2 & 28,1 & 5,2 & 37,5 & 54,2 & 1 & 3647 & 618 \\
\hline Elbasan-S & 4,5 & 5,2 & 48,9 & 20,8 & 26,3 & 1,0 & 43,4 & 49,1 & 1 & 5482 & 1093 \\
\hline Southeast & 4,4 & 7,0 & 57,4 & 20,8 & 29,9 & 3,4 & 50,3 & 42,8 & 1 & 6724 & 1418 \\
\hline urban & 2,6 & 5,3 & 62,9 & 19,5 & 30,3 & 6,5 & 55,8 & 33,6 & 1 & 57965 & 12857 \\
\hline Poland-Lithuania 18th c. & 4,5 & 3,0 & 64,3 & 20,0 & 24,0 & 1,2 & 27,6 & 53,5 & 0 & 127847 & 21132 \\
\hline PL West & 4,5 & 2,9 & 69,4 & 22,5 & 27,3 & 1,8 & 30,8 & 56,8 & 0 & 47938 & 7921 \\
\hline $\mathrm{PL} 1$ & 4,5 & 3,5 & 83,9 & 25,1 & 28,5 & 0,9 & 25,8 & 62,9 & 0 & 2543 & 545 \\
\hline PL2 & 4,5 & 3,6 & 78,1 & 24,0 & 28,9 & 2,5 & 34,6 & 51,5 & 0 & 4559 & 646 \\
\hline PL3 & 4,5 & 3,2 & 71,1 & 21,5 & 27,8 & 2,8 & 29,9 & 58,0 & 0 & 12893 & 1984 \\
\hline PL4 & 4,5 & 3,7 & 75,1 & 22,3 & 26,4 & 1,3 & 32,1 & 53,1 & 0 & 8358 & 1317 \\
\hline PL5 & 4,5 & 2,2 & 57,1 & 22,1 & 26,6 & 1,6 & 25,7 & 64,2 & 0 & 8320 & 1562 \\
\hline PL6+7 & 4,5 & 2,3 & 71,6 & 21,4 & 27,8 & 1,2 & 34,2 & 54,4 & 0 & 11265 & 1867 \\
\hline PL East & 4,6 & 3,0 & 61,5 & 18,4 & 22,0 & 0,7 & 25,6 & 51,5 & 0 & 79909 & 13211 \\
\hline PL8 & 4,6 & 2,5 & 58,1 & 18,2 & 23,6 & 0,8 & 24,7 & 45,2 & 0 & 25193 & 4520 \\
\hline PL10 & 4,6 & 3,0 & 60,5 & 19,1 & 23,1 & 1,2 & 26,6 & 52,0 & 0 & 14026 & 2100 \\
\hline PL11N & 4,6 & 3,7 & 63,1 & 20,3 & 24,2 & 0,6 & 23,3 & 53,3 & 0 & 16285 & 2855 \\
\hline PL11S & 4,6 & 3,2 & 64,4 & 16,7 & 19,9 & 0,4 & 27,3 & 53,3 & 0 & 24405 & 3736 \\
\hline
\end{tabular}


TABLE 2 Census samples by percent of stem and joint families among the aged

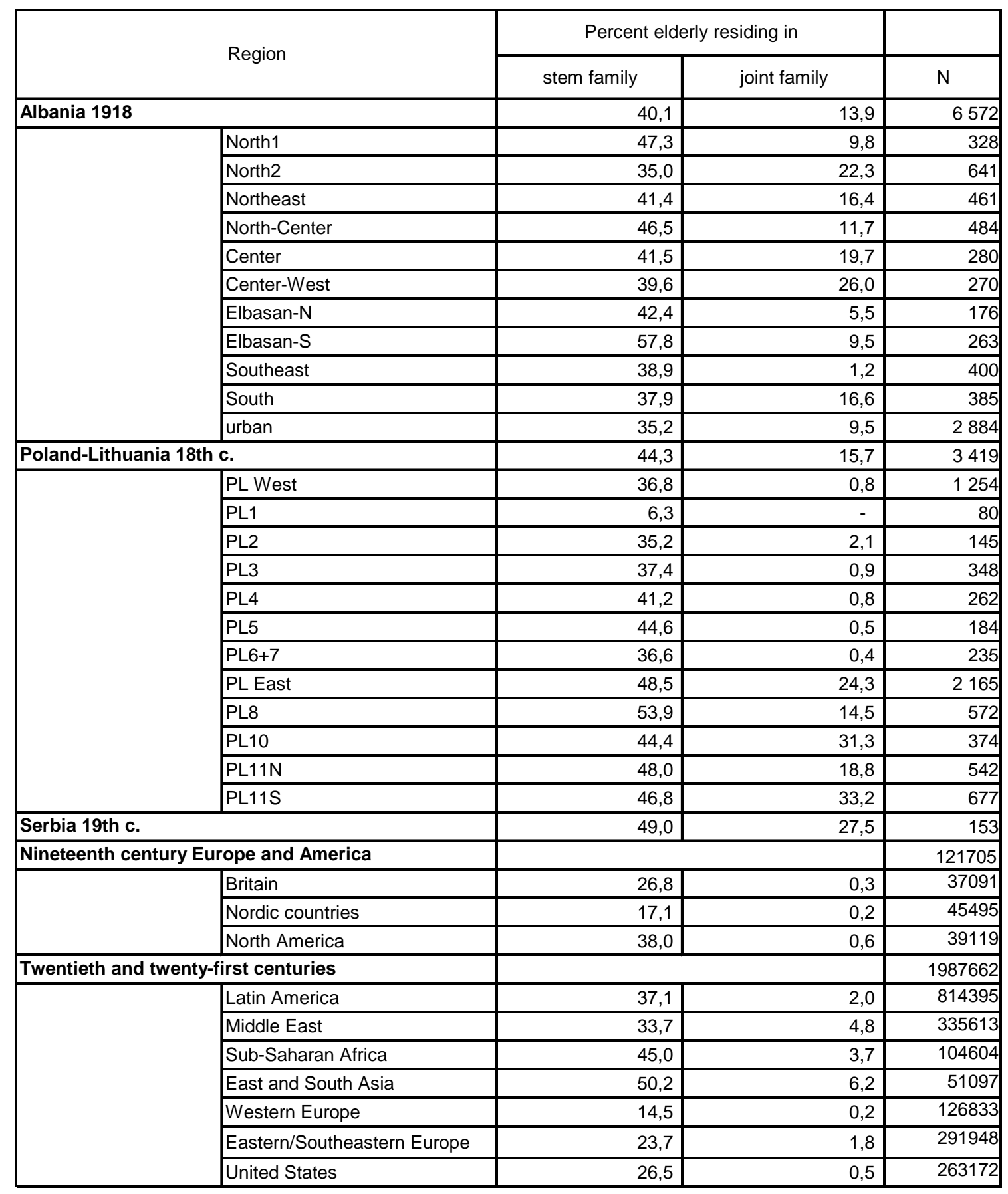


FIGURE 1A Predicted and observed percent of elderly in stem families (104 census samples)

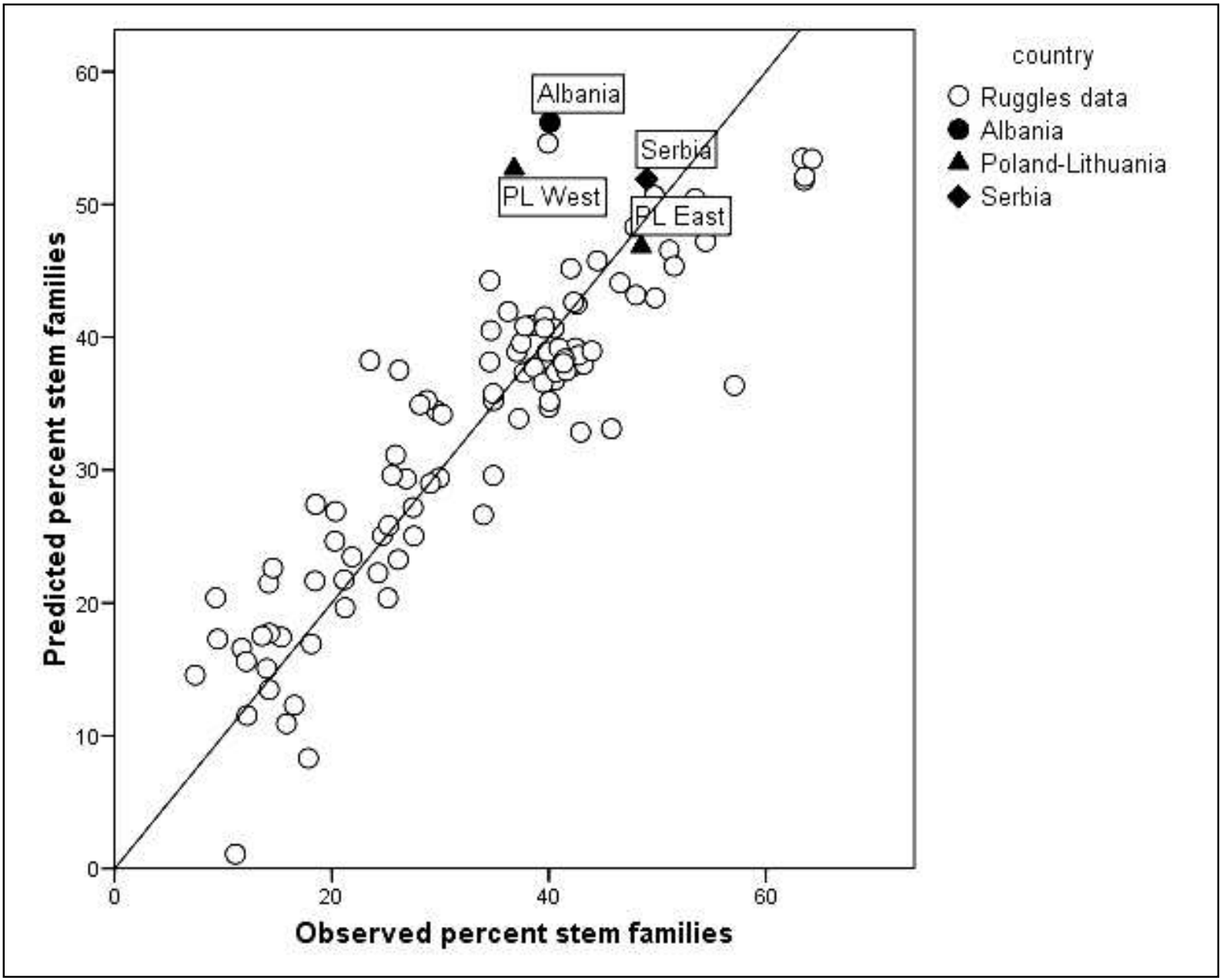


FIGURE 1B Predicted and observed percent of elderly in joint families (104 census samples)

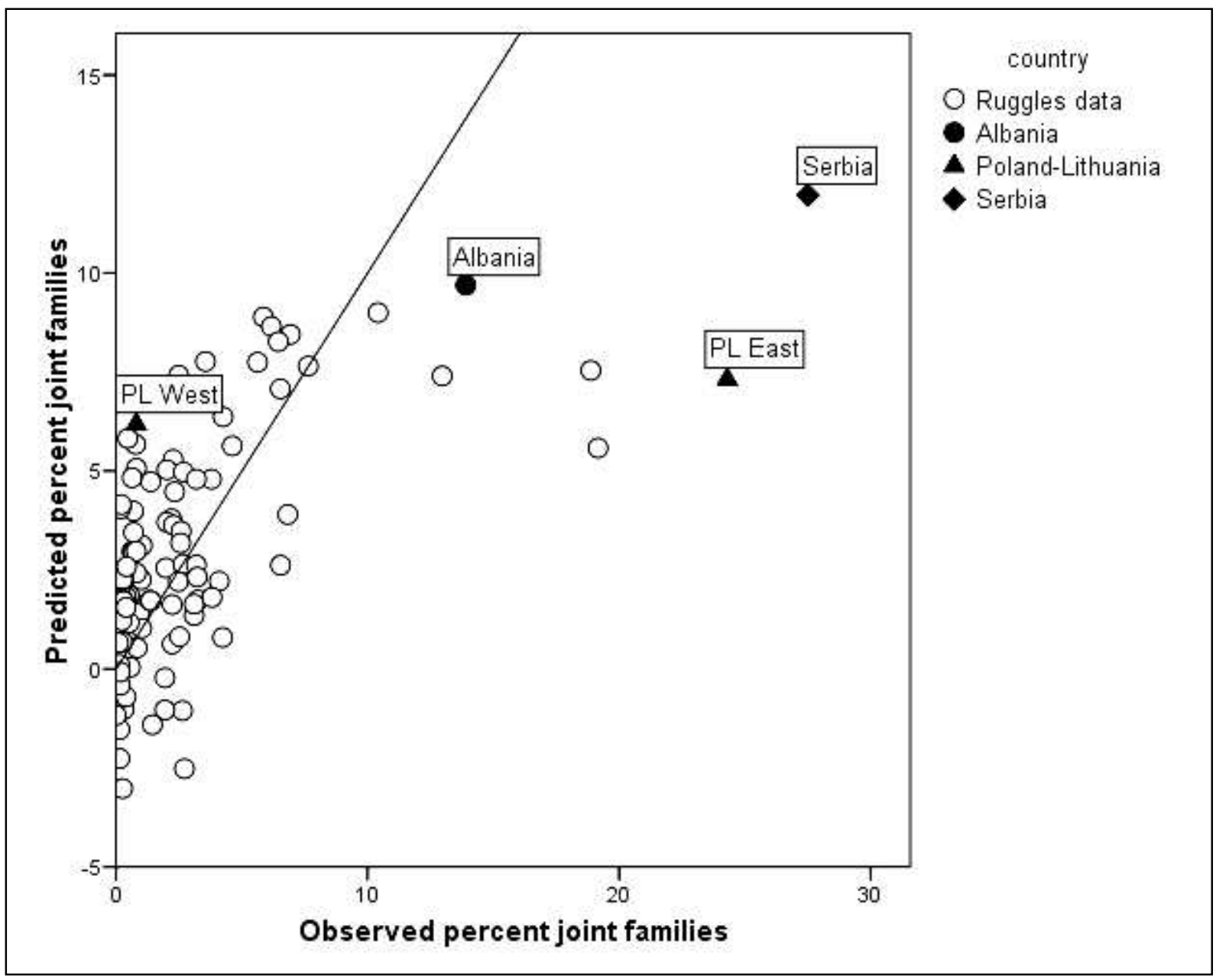


TABLE 3 OLS regressions of agricultural employment and demographic characteristics on stem and joint families (122 census samples)

\begin{tabular}{|l|c|c|r|c|}
\hline & \multicolumn{2}{|c|}{ Stem family } & \multicolumn{2}{c|}{ Joint family } \\
\hline & \multicolumn{1}{|c|}{$\mathrm{B}$} & Standard error & \multicolumn{1}{c|}{$\mathrm{B}$} & Standard error \\
\hline Agricultural employment & \multicolumn{1}{|c|}{2,71} & $1.17^{*}$ & 0,96 & 0,80 \\
\hline Percent elderly & $-2,91$ & $0.31^{* * *}$ & $-0,11$ & 0,21 \\
\hline Marital fertility & $-0,28$ & $0.05^{* * *}$ & 0 & 0,03 \\
\hline Female SMAM & $-0,22$ & 0,49 & $-0,97$ & $0.34^{* *}$ \\
\hline Male SMAM & 0,01 & 0,54 & 0,11 & 0,37 \\
\hline Nonmarriage & $-0,29$ & 0,24 & $-0,52$ & $0.17^{* *}$ \\
\hline Unmarried elderly women & 0,51 & $0.20^{*}$ & $-0,13$ & 0,14 \\
\hline Elderly couples & 0,01 & 0,20 & $-0,20$ & 0,14 \\
\hline De jure census & $-3,24$ & $1.42^{*}$ & 1,35 & 0,97 \\
\hline & & & & \\
\hline Constant & 49,36 & $17.26^{* *}$ & 37,42 & $11.82^{* *}$ \\
\hline Adjusted R square & $\mathbf{0 , 6 8}$ & & $\mathbf{0 , 4 1}$ & \\
\hline $\mathbf{N}$ & $\mathbf{1 2 2}$ & & $\mathbf{1 2 2}$ & \\
\hline${ }^{* * *} \mathrm{p}<.001 ;{ }^{* *} \mathrm{p}<.01 ;{ }^{*} \mathrm{p}<.05$ & & & & \\
\hline
\end{tabular}


FIGURE 2A Predicted and observed percent of elderly in stem families (122 census samples)

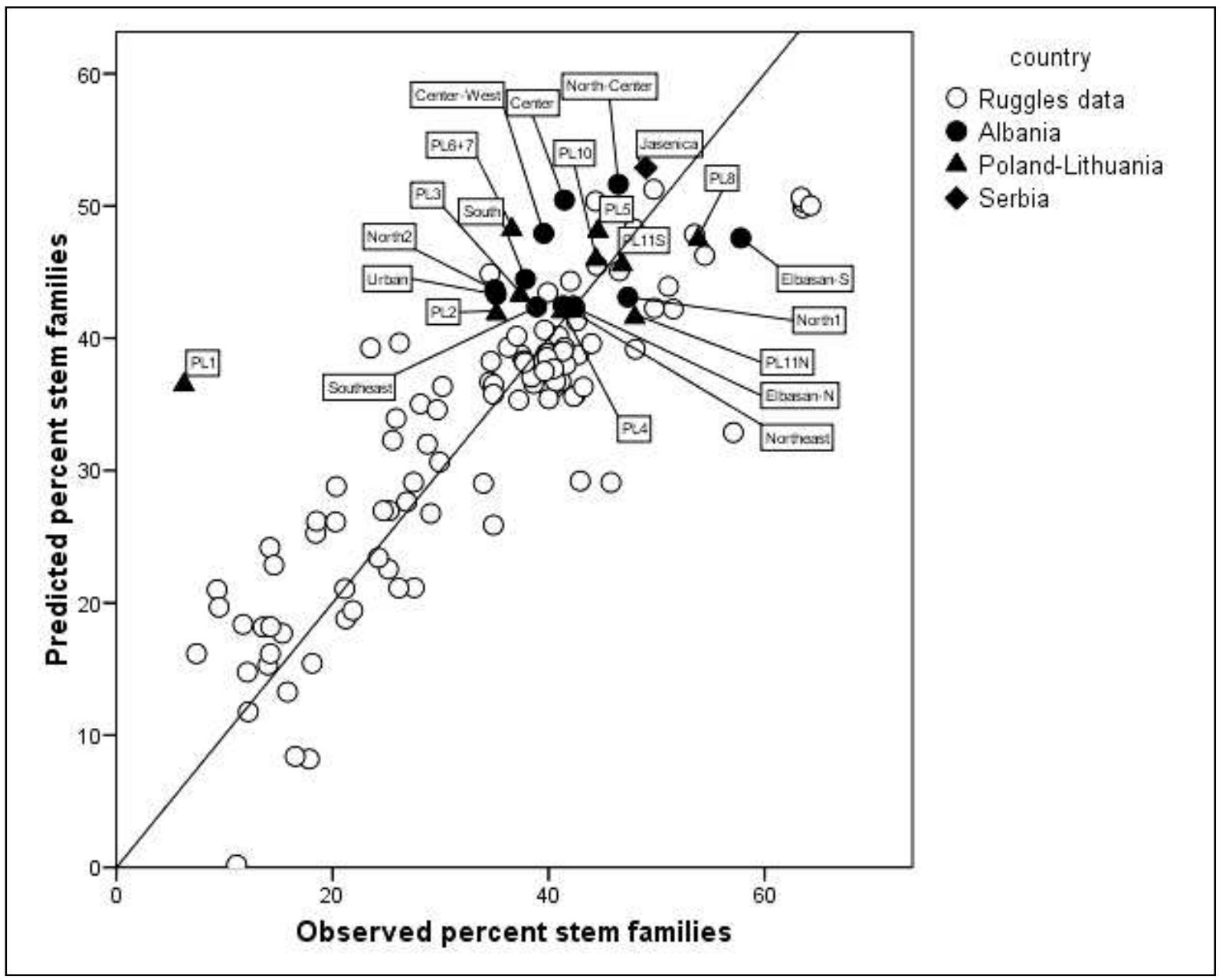


FIGURE 2B Predicted and observed percent of elderly in joint families (122 census samples)

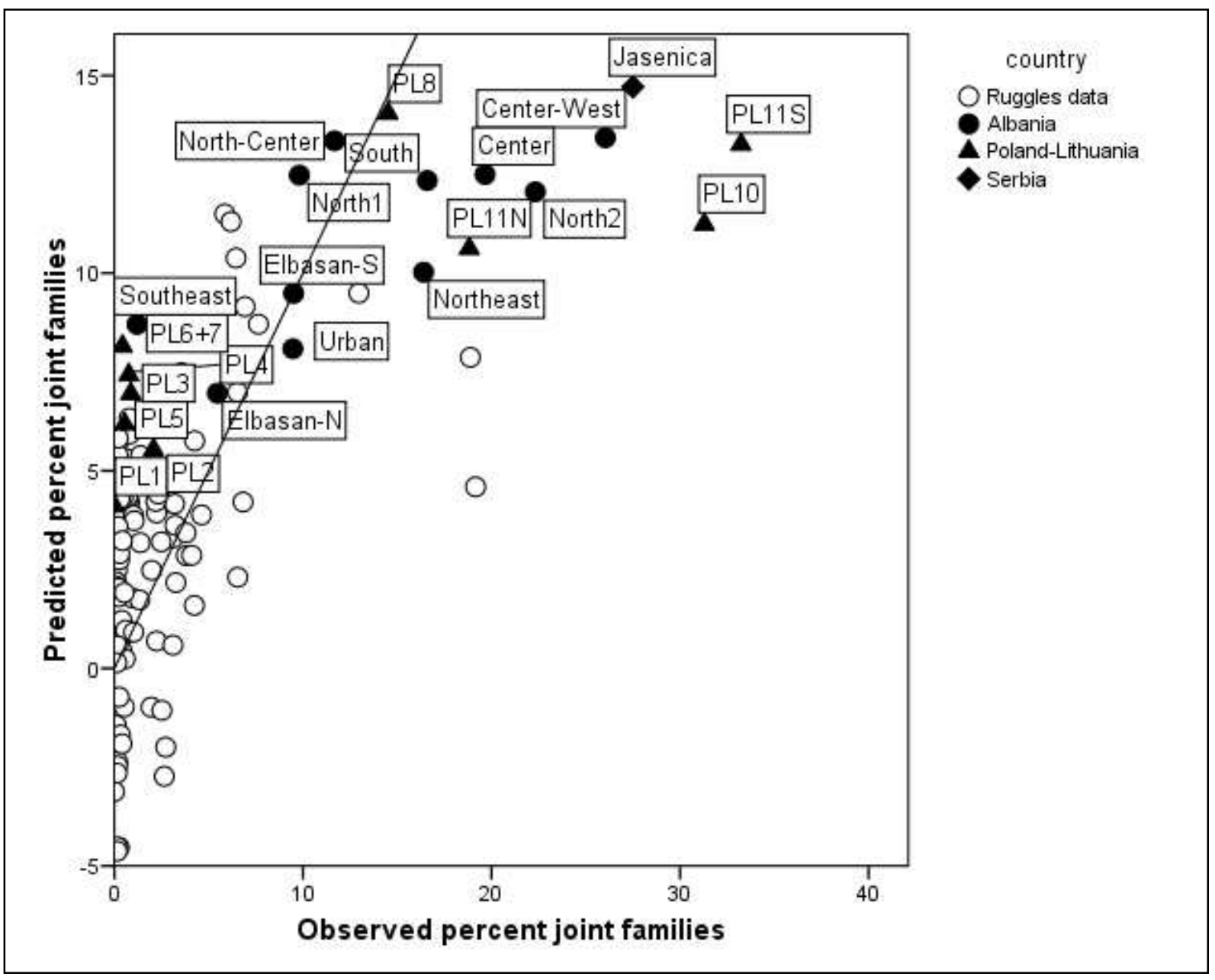


TABLE 4 OLS regressions of agricultural employment and demographic characteristics on joint families ( 59 census samples)

\begin{tabular}{|l|c|c|}
\hline & \multicolumn{2}{|l|}{ Joint family } \\
\hline & \multicolumn{1}{|c|}{ B } & Standard error \\
\hline Agricultural employment & $-0,47$ & 1.42 \\
\hline Percent elderly & 0,85 & $0.40^{*}$ \\
\hline Marital fertility & 0,11 & 0.06 \\
\hline Female SMAM & $-1,62$ & $0.43^{* * *}$ \\
\hline Male SMAM & $-0,88$ & 0.47 \\
\hline Nonmarriage & $-0,77$ & $0.24^{* *}$ \\
\hline Unmarried elderly women & $-0,41$ & $0.19^{*}$ \\
\hline Elderly couples & $-0,15$ & 0.18 \\
\hline De jure census & 5,60 & $1.66^{* *}$ \\
\hline & & \\
\hline Constant & 81.22 & $20.23^{* * *}$ \\
\hline Adjusted R square & $\mathbf{0 . 5 7}$ & \\
\hline $\mathbf{N}$ & $\mathbf{5 9}$ & \\
\hline${ }^{* * *} \mathrm{p}<.001 ;{ }^{* *} \mathrm{p}<.01 ;{ }^{*} \mathrm{p}<.05$ & & \\
\hline
\end{tabular}


FIGURE 2C Predicted and observed percent of elderly in joint families (59 census samples)

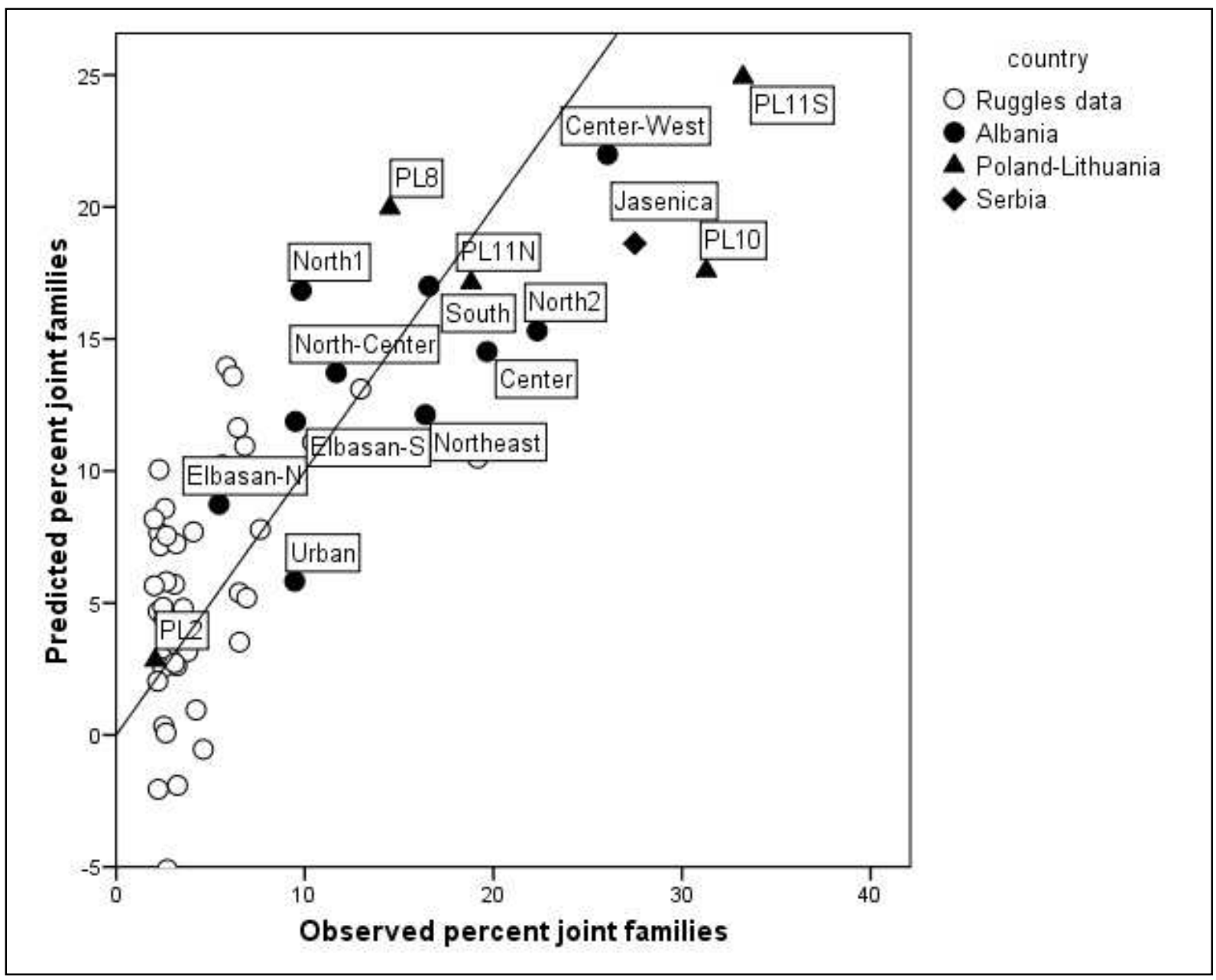


FIGURE 3A Percent of elderly in stem families measured with Ruggles' and our definitions ( 59 census samples)

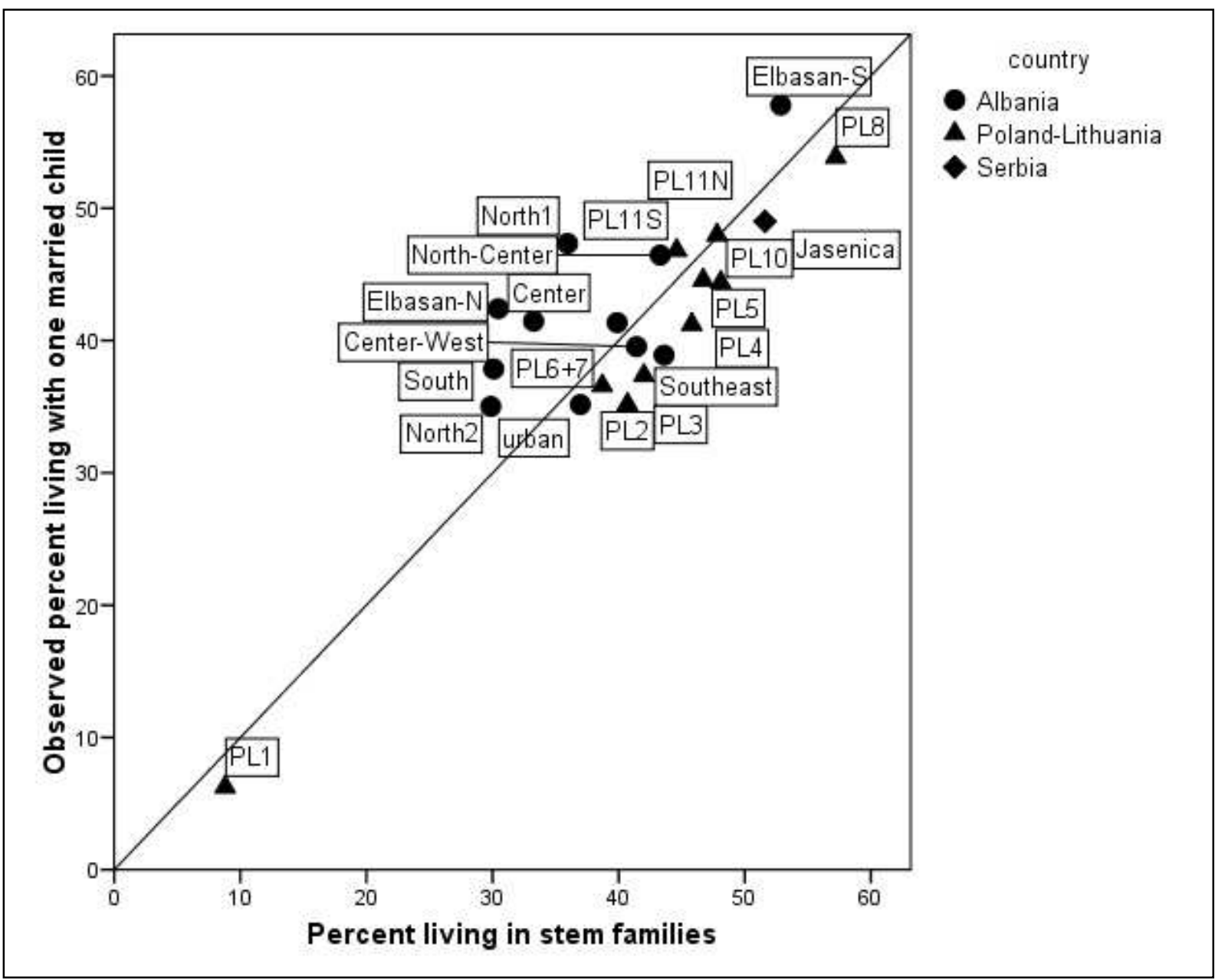


FIGURE 3B Percent of elderly in joint families measured with Ruggles' and our definitions ( 59 census samples)

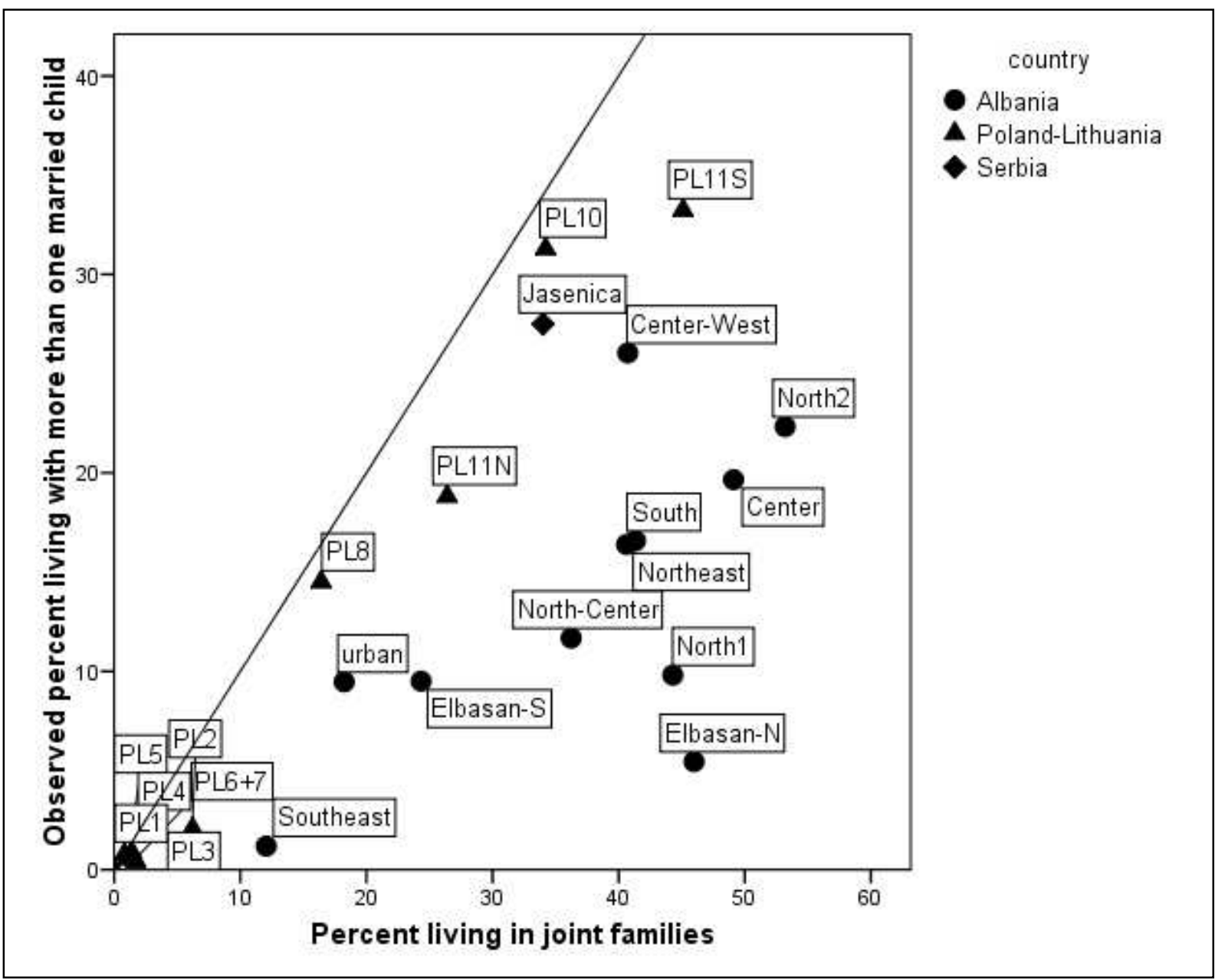


TABLE 5 Percentage changes in living arrangements caused by changing definitions from Ruggles to our new definition, based on Ruggles' definition

\begin{tabular}{|l|c|c|c|}
\hline $\begin{array}{l}\text { Type of } \\
\text { change }\end{array}$ & Albania & Poland-Lithuania & Serbia \\
\hline $\begin{array}{l}\text { stem families } \\
\text { becoming joint } \\
\text { families }\end{array}$ & 23.4 & 4.9 & 4.0 \\
\hline $\begin{array}{l}\text { other families } \\
\text { becoming stem } \\
\text { families }\end{array}$ & 12.5 & 10.1 & 19.4 \\
\hline $\begin{array}{l}\text { other families } \\
\text { becoming joint } \\
\text { families }\end{array}$ & 30.6 & 5.9 & 19.4 \\
\hline
\end{tabular}

